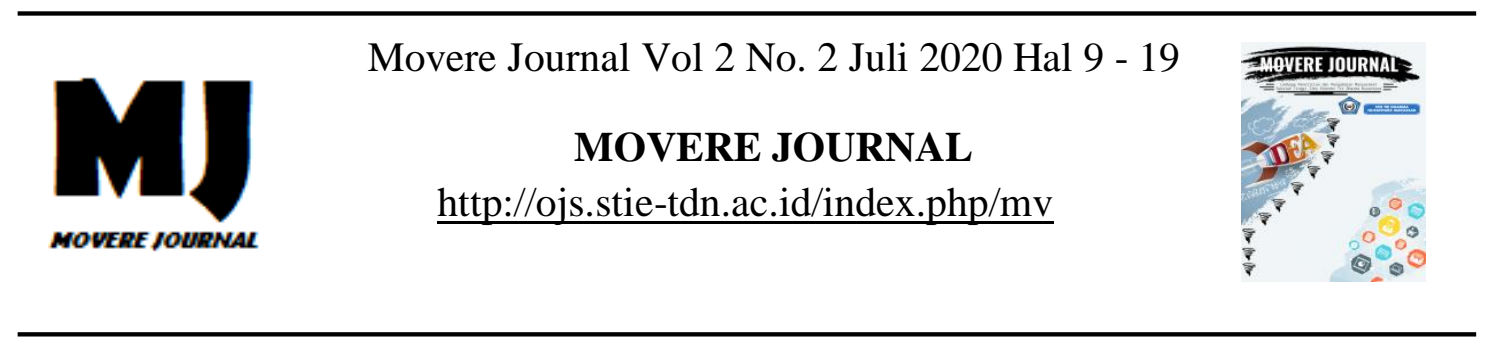

\title{
PENGARUH LIKUIDITAS DAN PROFITABILITAS TERHADAP KEBIJAKAN DEVIDEN PADA KELOMPOK SAHAM JAKARTA ISLAMIC INDEX YANG TERDAFTAR DI BURSA EFEK INDONESIA
}

Andi Sartika Juniarmita

STIE Tri Dharma Nusantara Makassar

\begin{abstract}
Abstrak: Penelitian ini bertujuan untuk: (i) menganalisis pengaruh tingkat Likuiditas terhadap kebijakan deviden pada kelompok saham Jakarta Islamic Index, (ii) menganalisis pengaruh tingkat Solvabilitas terhadap kebijakan deviden pada kelompok saham Jakarta Islamic Index. Pendekatan dalam penelitian ini adalah pendekatan kuantitatif deskriptif. Penelitian ini dilakukan dengan mengambil data di Bursa Efek Indonesia (BEI) serta di kantor perwakilan Bursa Efek Indonesia yaitu PT IDX Cabang Makassar yang berlokasi di Jalan Sam Ratulangi Makassar. Jenis data dalam penelitian ini ialah data kualitatif dan data kuantitatif. Sumber data yang digunakan adalah data sekunder. Teknik pengumpulan data dalam penelitian ini adalah menggunakanmetode dokumentasi dari Bursa Efek Indonesia (BEI) melalui PIPM dan www.idx.co.id. Populasi yang dipilih dalam penelitian adalah seluruh perusahaan Jakarta Islamic Index (JII) yang terdaftar di Bursa Efek Indonesia (BEI)yang berjumlah 30 perusahaan dan selama periode pengamatan (2013-2016). Sampel yang memenuhi syarat adalah sebanyak 10 perusahaan. Metode analisis yang digunakan adalah teknik analisis regresi berganda dan uji hipotesis menggunakan t-statistik untuk menguji koefisien regresi parsial dengan tingkat signifikansi 5\%. Hasil analisis menunjukkan bahwa: (i) Likuiditas yang diukur dengan current ratio (CR) menunjukkan bahwa likuiditas berpengaruh positif dan signifikan terhadap kebijakan deviden, (ii) Profitabilitas yang diukur dengan net profit margin (NPM) menujukkan profitabilitas berpengaruh positif dan signifikan terhadap kebijakan deviden.
\end{abstract}

Kata Kunci : Likuiditas, Profitabilitas dan Kebijakan Dividen 


\section{PENDAHULUAN}

\section{Latar Belakang}

Menurut UU Pasar Modal No.8 Tahun 1995, pasar modal merupakan kegiatan yang bersangkutan dengan penawaran umum dan perdagangan efek, perusahaan publik yang berkaitan dengan efek yang diterbitkannya, serta lembaga dan profesi yang berkaitan dengan efek. Fungsi pasar modal mempertemukan antara pemilik dana (investor) dan pengguna dana (perusahaan yang perlu dana).

Di bursa Efek Indonesia terdapat beberapa jenis indeks, namun di antara tersebut yang beroperasi berdasarkan prinsip syariah adalah Jakarta Islamic Index (JII) dan indeks Saham Syariah Indonesia (ISSI). Jakarta Islamic Index merupakan indeks yang terdiri dari 30 saham yang memiliki bidang usaha sesuai syariah islam dan dievaluasi tiap 6 bulan sekali dengan penentuan komponen indeks awal bulan Januari dan Juli setiap tahunnya.

JII merupakan saham syariah yang memilki urutan paling tinggi, dinilai berdasarkan tingkat likiuditas rata-rata nilai perdagangan regular selama 1 (satu) tahun terakhir (ibid, h.129). Indeks Saham Syariah Indonesia terdiri dari seluruh saham syariah yang tercatat di BEI yang telah diluncurkan oleh Bursa Efek Indonesia pada tanggal 12 Mei 2011 (Anonim, syariah, http://www.idx.co.id). Namun pada penelitian ini,peneliti hanya berfokus pada Jakarta Islamic Index. Indeks saham JII merupakan indeks yang sangat diminati oleh investor di pasar modal, dalam berinvestasi di pasar modal

Corresponding Author: Andisartikaaa@gmail.com terdapat dua bentuk return yang diharapkan oleh pemegang saham yaitu capital gain dan dividend yield, Kinerja saham JII yang melejit setiap tahunnya.

Jakarta Islamic Index atau biasa disebut JII adalah salah satu indeks saham yang ada di Indonesia yang menghitung index harga rata-rata saham untuk jenis saham-saham yang memenuhi kriteria syariah. Darmadji dan Hendy (2011:184) JII telah dikembangkan sejak tanggal 3 Juli 2000. Pembentukan instrumen syariah ini untuk mendukung pembentukan Pasar Modal Syariah yang kemudian diluncurkan di Jakarta pada tanggal 14 Maret 2003. Mekanisme Pasar Modal Syariah meniru pola serupa di Malaysia yang digabungkan dengan bursa konvensional seperti Bursa Efek Jakarta dan Bursa Efek Surabaya. Setiap periodenya, saham yang masuk JII berjumlah 30 (tiga puluh) saham yang memenuhi kriteria syariah.

Tujuan pembentukan JII adalah untuk meningkatkan kepercayaan investor untuk melakukan investasi pada saham berbasis syariah dan memberikan manfaat bagi pemodal dalam menjalankan syariah Islam untuk melakukan investasi di bursa efek. JII juga diharapkan dapat mendukung proses transparansi dan akuntabilitas saham berbasis syariah di Indonesia. JII menjadi jawaban atas keinginan investor yang ingin berinvestasi sesuai syariah. Dengan kata lain, JII menjadi pemandu bagi investor yang ingin menanamkan dananya secara syariah tanpa takut tercampur dengan dana ribawi. Selain itu, JII menjadi tolak ukur kinerja (benchmark) dalam memilih portofolio saham yang halal.

(c) 2020 STIE TDN. All rights reserved 
Pentingnya likuiditas dapat dilihat dengan mempertimbangkan dampak yang berasal dari ketidakmampuan perusahaan memenuhi kewajiban jangka pendeknya. Kurangnya likuiditas menghalangi perusahaan untuk memperoleh keuntungan dari diskon atau kesempatan mendapatkan keuntungan.

Likuiditas perusahaan dapat dianalisis dengan menggunakan berbagai rasio keuangan yang disebut dengan rasio likuiditas. Rasio likuiditas menggambarkan kemampuan perusahaan untuk menyelesaikan kewajiban jangka pendeknya. Rasiorasio ini dapat dihitung melalui sumber informasi tentang modal kerja yaitu pospos aktiva lancar dan utang lancar.

Profitabilitas menggambarkan kemampuan perusahaan mendapatkan laba melalui semua kemampuan, dan sumber yang ada seperti kegiatan penjualan, kas, modal, jumlah karyawan, jumlah cabang dan sebagainya. Rasio yang menggambarkan kemampuan perusahaan menghasilkan laba disebut juga Operating Rasio. Rasio ini menunjukkan berapa besar persentase pendapatan bersih yang diperoleh dari setiap penjualan. Semakin besar rasio ini semakin baik karena dianggap kemampuan peusahaan dalam mendapat laba cukup tinggi.

Pada perseroan terbatas, pembagian keuntungan kepada pemilik dilakukan melalui dividen. Dividen hanya dapat dibayarkan jika saldo laba ditahan positif. Jadi, walaupun dalam tahun berjalan diperoleh laba, suatu perseroan terbatas tidak boleh membagikan dividen jika saldo laba ditahan pada akhir tahun masih negatif.

Corresponding Author: Andisartikaaa@gmail.com
Kedua rasio ini dipilih karena menurut peneliti dalam melakukan pembagian dividen perusahaan sangat perlu memperhatikan kinerja mereka dari sisi likuiditas yang memadai serta bagaimana perusahaan menghasilkan laba untuk memenuhi kewajiban jangka pendek dan jangka panjangnya.

Berdasarkan latar belakang penelitian diatas maka peneliti mengangkat judul yang dibahas mengenai "Pengaruh Likuiditas dan Profitabilitas Terhadap Kebijakan Deviden Pada Kelompok Saham Jakarta Islamic Index yang Terdaftar di Bursa Efek Indonesia”.

\section{Rumusan Masalah}

Apakah likuiditas dan profitabilitas berpengaruh terhadap kebijakan deviden pada kelompok saham Jakarta Islamic Index yang terdaftar di Bursa Efek Indonesia".

\section{Tujuan Penelitian}

Tujuan penelitian ini untuk: (i) menganalisis pengaruh tingkat Likuiditas terhadap kebijakan deviden pada kelompok saham Jakarta Islamic Index, (ii) menganalisis pengaruh tingkat Solvabilitas terhadap kebijakan deviden pada kelompok saham Jakarta Islamic Index.

\section{Pasar Modal}

Menurut UU Pasar Modal No.8 Tahun 1995, pasar modal merupakan kegiatan yang bersangkutan dengan penawaran umum dan perdagangan efek, perusahaan publik yang berkaitan dengan efek yang diterbitkannya, serta lembaga dan profesi yang berkaitan dengan efek. Fungsi pasar modal 
mempertemukan antara pemilik dana (investor) dan pengguna dana (perusahaan yang perlu dana).

\section{Liquiditas}

Rasio likuiditas menggambarkan kemampuan perusahaan dalam melunasi kewajiban jangka pendeknya. Kewajiban jangka pendek atau utang lancar adalah utang yang akan dilunasi dalam waktu satu tahun. Dalam rutinitas sehari-hari, likuiditas antara lain akan tercermin dalam bentuk kemampuan perusahaan dalam membayar kreditur tepat waktu atau membayar gaji tepat waktu. Likuiditas mengacu pada ketersediaan sumber daya perusahaan untuk memenuhi kebutuhan kas jangka pendek. Risiko likuiditas perusahaan jangka pendek dipengaruhi oleh kapan arus kas masuk dan arus kas keluar terjadi serta prospek arus kas untuk kinerja masa depan. Will dalam Vandan Wachowicz (2007:184).

\section{Profitabilitas}

Profitabilitas menggambarkan kemampuan perusahaan mendapatkan laba melalui semua kemampuan, dan sumber yang ada seperti kegiatan penjualan, kas, modal, jumlah karyawan, jumlah cabang dan sebagainya. Rasio yang menggambarkan kemampuan perusahaan menghasilkan laba disebut juga Operating Rasio. Rasio ini menunjukkan berapa besar persentase pendapatan bersih yang diperoleh dari setiap penjualan. Semakin besar rasio ini semakin baik karena dianggap kemampuan peusahaan dalam mendapat laba cukup tinggi.

\section{Deviden}

Corresponding Author: Andisartikaaa@gmail.com 12
Riyanto (2001:265) mengemukakan dividen merupakan aliran kas yang dibayarkankepada para pemegang saham (equity investors). Keuntungan para pemegang saham atau investor dapat berupa dividen dan capital gain. Keuntungan yang didapat dari selisih lebih antara harga jual saham dengan harga beli saham disebut capital gain. Weston dan Copeland dalam Radoni dan Herni (2010:121) menyatakan Dividen adalah keuntungan perusahaan yang berbentuk perseroan terbatas yang diberikan kepada para pemegang saham. Besarnya dividen yang diberikan ditentukan dalam rapat pemegang saham dan dinyatakan dalam suatu jumlah atau persentase (\%) tertentu atas nilai nominal saham dan bukan atas nilai pasarnya.

\section{METODE PENELITIAN}

\section{Metode Pengumpulan Data}

Pendekatan dalam penelitian ini adalah pendekatan kuantitatif deskriptif, karena penelitian ini disajikan dalam bentuk angka-angka. Penelitian kuantitatif merupakan pendekatan penelitian yang banyak dituntut menggunakan angka mulai dari pengumpulan data, penafsiran terhadap data tersebut, serta penampilan hasilnya.

Penelitian ini dilakukan dengan mengambil data di Bursa Efek Indonesia (BEI) serta di kantor perwakilan Bursa Efek Indonesia yaitu PT IDX Cabang Makassar yang berlokasi di Jalan Sam Ratulangi Makassar dan waktu penelitian selama \pm 2 bulan yaitu bulan april sampai dengan bulan Mei 2018.

Data kuantitatif merupakan data dapat

(c) 2020 STIE TDN. All rights reserved 
dihitung berupa laporan keuangan yang berhubungan dengan variabel penelitian yaitu, likuiditas, profitabilitas dan kebijakan deviden yang diperoleh dari Bursa Efek Indonesia (BEI) dan termasuk dalam kategori saham Jakarta Islamic index

Data kualitatif merupakan data yang diperoleh dalam bentuk informasi baik lisan maupun tulisan, seperti data dari karya ilmiah, literature dan jurnal.

\section{Jenis dan Sumber Data}

Dalam penelitian ini sumber data yang digunakan adalah data sekunder. yang mana data yang diperoleh melalui sumber tertulis di Bursa Efek Indonesia (BEI) baik itu berupa dokumendokumen perusahaan ataupun informasi tertulis lainnya yang mempunyai kaitan langsung dengan permasalahan penelitian. Data yang digunakan dalam penelitian diperoleh dari Indonesia Capital Market Directory (ICMD) dan www.idx.co.id.

Teknik pengumpulan data dalam penelitian ini adalah menggunakan metode dokumentasi dari Bursa Efek Indonesia (BEI) melalui PIPM dan www.idx.co.id yang dilakukan dengan mengambil dokumen dan informasi data berupa data laporan keuangan dari kelompok saham Jakarta Islamic Index (JII) yang terdaftar di Bursa Efek Indonesia (BEI) selama 4 tahun (20132016).

\section{Populasi dan Sampel}

1. Populasi

Populasi yang dipilih dalam penelitian adalah seluruh perusahaan Jakarta Islamic Index (JII) yang terdaftar di Bursa Efek Indonesia (BEI)

Corresponding Author: Andisartikaaa@gmail.com yang berjumlah 30 perusahaan dan selama periode pengamatan (20132016). Berikut daftar perusahaan Jakarta Islamic index (JII).

2. Sampel

Adapun penarikan sampel dari jumlah populasi dilakukan dengan menggunakan metode purposive sampling dengan memperhatikan perusahaan yang memiliki kriteria sebagai berikut:

a. Perusahaan yang terdaftar di Bursa Efek Indonesia dan konsisten masuk dalam kategori Jakarta Islamic Index (JII) selama tahun 2013-2016.

b. Perusahaan JII yang menerbitkan laporan keuangannya selama periode penelitian.

c. Perusahaan JII yang pernah membagikan dividen selama periode pengamatan.

Berdasarkan kriteria sampel tersebut, maka pada penelitian ini sampel yang memenuhi syarat adalah sebanyak 10 perusahaan.

\section{Metode Analisis Data}

Teknik analisis data untuk mengukur variabel-variabel dalam penelitian ini, menggunakan software SPSS, dengan cara memasukkan hasil dari operasionalisasi variabel yang akan di uji.

1. Regresi Linier Berganda

Regresi bertujuan untuk menguji hubungan pengaruh variabel independen terhadap variabel dependen, apakah masing-masing variabel independen berhubungan positif atau negatif dan untuk memprediksi nilai dari variabel independen mengalami kenaikan atau penurunan. 
2. Uji Hipotesis

Uji hipotesis dilakukan untuk mengetahui apakah variabel likuiditas dan profitabilitas berpengaruh terhadap dividendpayout ratio. Pengujian ini menggunakan uji Asumsi Klasik diantaranya: (a) Uji Normalitas, (b) Uji Auto korelasi

3. Uji Multikolinieritas

Uji Multikolinieritas bertujuan untuk menguji model regresi ditemukan adanya korelasi antar variabel bebas (independen). Model regresi yang baik seharusnya tidak terjadi korelasi diantara variabel independen. Nilai cut off yang umum dipakai untuk menunjukkan adanya multikolinieritas adalah nilai tolerance $<0,10$ atau sama dengan nilai VIF > 10. (Ghozali, 2005:91)

4. Uji Heteroskedastisitas

Uji Heteroskedastisitas bertujuan menguji apakah dalam model regresi terjadi ketidaksamaan variance dari residual satu pengamatan ke pengamatan yang lain. Cara melakukan uji Glejser dengan meregres nilai absolute residual sebagai variabel dependen terhadap variabel independen. (Ghozali, 2005:108).

5. Koefisien Determinasi

Hasil nilai adjusted R-Square dari regresi digunakan untuk mengetahui besarnya dividend payout ratio yang dipengaruhi oleh variabel-variabel bebasnya.

\section{Uji-t (Uji Parsial)}

Uji parsial (koefisien regresi) atau disebut dengan uji t, yaitu untuk menguji signifikan konstanta dan variabel independen yang terdapat dalam persamaan tersebut di atas secara individu apakah berpengaruh pada variabel dependen. Untuk pengujian ini

Corresponding Author: Andisartikaaa@gmail.com 14 dilakukan dengan cara: Bila probabilitas lebih besar dari 0.05 , maka variabel independen secara individu tidak berpengaruh terhadap variabel dependen. Sedangkan bila probabilitas lebih kecil dari 0.05, maka variabel independen berpengaruh terhadap variabel dependen.

\section{HASIL DAN PEMBAHASAN}

Objek pada penelitian ini adalah kelompok saham Jakarta Islamic Index (JII) yang terdaftar di Bursa Efek Indonesia. Data laporan keuangan kelompok saham Jakarta Islamic Index (JII) diperoleh dari Pusat Informasi Penanaman Modal (PIPM) Makassar dan Bursa Efek Indonesia (BEI) atau www.idx.co.id.

Pengamatan terhadap likuiditas, solvabilitas dan profitabilitas terhadap kebijakan deviden pada kelompok saham Jakarta Islamic Index dilakukan dari tahun 2013-2016. Pengambilan sampel dilakukan secara purposive sampling, sehingga perusahaan yang memenuhi kriteria untuk dijadikan sampel adalah 10 perusahaan.

Kebijakan deviden di Bursa Efek Indonesia dapat dilihat dari laporan keuangan pada kelompok saham Jakarta Islamic Index (JII) selama tahun 2013 sampai 2016. Adapun untuk tujuan analisis ini akan mengkaji kebijakan deviden dari 10 perusahaan kelompok saham Jakarta Islamic Index (JII) di Bursa Efek Indonesia yakni: (1) Adaro Energy, (2) AKR Corporindo, (3) Astra Indonesia, (4) PP London Sumatra Indonesia, (5) Indofood CBP Sukses Makmur, (6) Kalbe Farma, (7) Tambang Batu Bara Bukit Asam, (8) Telekomunikasi Indonesia, (9) United Tractors, (10) Unilever Indonesia.

(C) 2020 STIE TDN. All rights reserved 
Kebijakan deviden adalah keputusan direksi apakah laba yang dihasilkan perusahaan pada akhir periode dibagikan kepada pemilik saham (deviden) atau laba tersebut ditahan sebagai penambah modal perusahaan yang akan digunakan dalam kegiatan atau investasi pengembangan persuhaan dimasa mendatang. Kebijakan deviden selalu berkaitan langsung dengan keputusan pendanaan perusahaan.

Kebijakan deviden diukur dengan menggunakan dividend payout ratio (DPR). DPR adalah rasio yang menunjukkan persentase setiap keuntungan yang didistribusikan kepada pemegang saham dalam bentuk uang tunai. Dividen Payout Ratio (Rasio Pembayaran Dividen) yang dihitung dengan melihat persentase laba yang dibayarkan dalam bentuk deviden atau dengan total laba yang tersedia bagi pemegang saham.

$$
\text { DPR }=\frac{\text { Deviden PerLembar Saham }}{\text { Laba PerLembar Saham }} X 100 \%
$$

Berdasarkan rumus diatas, maka perhitungan kebijakan deviden pada kelompok saham Jakarta Islamic Index (JII) di Bursa Efek Indonesia selama tahun 2013 sampai 2016, dapat dilihat pada table berikut ini.

Tabel 5, Kebijakan Deviden (DPR) pada kelompok saham Jakarta Islamic
Index di Bursa Efek Indonesia Tahun 2013-2016
\begin{tabular}{|c|l|c|c|c|c|}
\hline \multirow{2}{*}{ No } & \multirow{3}{*}{ Kode Perusahaan } & \multicolumn{5}{|c|}{$\begin{array}{c}\text { KEBIJAKAN DEVIDEN } \\
\end{array}$} & & 2013 & 2014 & 2015 & 2016 \\
\cline { 3 - 6 } & & 32.00 & 43.72 & 49.89 & 44.44 \\
\hline 1 & ADRO & 68.00 & 62.80 & 45.74 & 27.64 \\
\hline 2 & AKRA & 45.00 & 45.00 & 49.00 & 14.00 \\
\hline 3 & ASIl & 40.79 & 39.45 & 68.00 & 99.88 \\
\hline 4 & LSIP & 49.79 & 49.71 & 49.75 & 27.64 \\
\hline 5 & ICBP & 44.97 & 99.93 & 44.44 & 66.89 \\
\hline 6 & KLBF & 58.29 & 68.00 & 68.00 & 66.89 \\
\hline 7 & PTBA & 72.66 & 68.00 & 61.59 & 11.27 \\
\hline 8 & TLKM & 99.93 & 64.95 & 66.89 & 10.66 \\
\hline 9 & UNTR & 99.93 & 68.00 & 99.88 & 44.77 \\
\hline 10 & UNVR & & & \\
\hline Sumber: Www.idx.co.id &
\end{tabular}

Corresponding Author: Andisartikaaa@gmail.com
Dari table diatas dapat dilihat Tingkat kebijkan deviden yang dibagikan perusahaan pada index ini mengalami fluktuasi mulai tahun 2013-2016.

Data mengenai likuiditas yang diukur dengan menggunakan Current Ratio diperoleh dari laporan kinerja 10 perusahaan dalam Jakarta Islamic Index (JII) yang termasuk objek penelitian pada periode 2013-2016. Data tersebut dipublikasikan pada Bursa Efek Indonesia sebagai salah satu informasi kepada para investor dan pemangku kepentingan lainnya Berikut adalah tingkat Current Ratio (CR) perusahaan yang termasuk dalam kategori Jakarta Islamic Index yang akan diteliti pada penelitian ini:

Tabel 6.Likuiditas (CR) pada kelompok saham Jakarta Islamic Index di
\begin{tabular}{|c|l|c|c|c|c|}
\hline \multirow{3}{*}{ Bursa Efek Indonesia Tahun 2013-2016 } \\
\hline \multirow{2}{*}{ Ko } & \multirow{5}{*}{ Kode Perusahaan } & \multicolumn{5}{c|}{ Current Ratio (\%) } \\
\cline { 3 - 6 } & & 2013 & 2014 & 2015 & 2016 \\
\hline 1 & ADRO & 177.00 & 191.02 & 240.39 & 71.49 \\
\hline 2 & AKRA & 177.00 & 249.11 & 149.56 & 127.09 \\
\hline 3 & ASII & 124.00 & 132.26 & 191.02 & 123.94 \\
\hline 4 & LSIP & 248.00 & 249.11 & 283.93 & 283.93 \\
\hline 5 & ICBP & 241.06 & 218.32 & 232.60 & 369.78 \\
\hline 6 & KLBF & 283.93 & 283.93 & 71.49 & 374.73 \\
\hline 7 & PTBA & 248.00 & 207.51 & 154.35 & 229.88 \\
\hline 8 & TLKM & 248.00 & 191.02 & 135.29 & 119.97 \\
\hline 9 & UNTR & 191.02 & 218.32 & 214.77 & 229.88 \\
\hline 10 & UNVR & 283.93 & 191.02 & 369.78 & 60.56 \\
\hline Sumber: www.idx.co.id & & & & \\
\hline
\end{tabular}

Tabel di atas dapat dilihat bahwa likuiditas perusahaan 4 tahun terakhir mengalami fluktuasi mulai tahun 20132016.

Data mengenai Profitabilitas yang diukur dengan menggunakan rasio Net profit Margin (NPM), diperoleh dari laporan kinerja 10 perusahaan dalam Jakarta Islamic Index (JII) yang termasuk objek penelitian pada periode 2013-2016. Data tersebut dipublikasikan pada Bursa Efek Indonesia sebagai salah satu informasi kepada para investor dan pemangku kepentingan lainnya. Berikut 
adalah tingkat Net profit margin (NPM) perusahaan yang termasuk dalam kategori Jakarta Islamic Index yang akan diteliti pada penelitian ini:

Tabel 8.Profitabilitas (NPM) pada kelompok saham Jakarta Islamic Index
\begin{tabular}{|c|l|c|c|c|c|} 
di Bursa Efek Indonesia Tahun 2013-2016 \\
\hline \multirow{3}{*}{ No } & \multirow{3}{*}{ Kode Perusahaan } & \multicolumn{5}{c|}{$\begin{array}{c}\text { PROFITABILITAS } \\
\text { Net Profit Margin (\%) }\end{array}$} \\
\cline { 3 - 6 } & & 2013 & 2014 & 2015 & 2016 \\
\hline 1 & ADRO & 6.00 & 9.41 & 5.63 & 23.91 \\
\hline 2 & AKRA & 9.41 & 3.52 & 16.63 & 6.88 \\
\hline 3 & ASII & 11.00 & 10.97 & 8.48 & 10.11 \\
\hline 4 & LSIP & 18.59 & 9.41 & 14.88 & 15.41 \\
\hline 5 & ICBP & 8.91 & 8.43 & 9.21 & 11.15 \\
\hline 6 & KLBF & 12.31 & 12.21 & 11.50 & 12.08 \\
\hline 7 & PTBA & 16.54 & 24.46 & 14.83 & 10.51 \\
\hline 8 & TLKM & 24.46 & 16.63 & 22.75 & 25.08 \\
\hline 9 & UNTR & 16.63 & 9.11 & 16.63 & 11.21 \\
\hline 10 & UNVR & 22.75 & 16.63 & 16.04 & 15.96 \\
\hline Sumber: www.idx.co.id & & & & \\
\hline
\end{tabular}

Tabel di atas dapat dilihat bahwa profitabilitas perusahaan 4 tahun terakhir mengalami fluktuasi mulai tahun 20132016.

1. Regresi Linear sederhana

Analisis pengaruh likuiditas dan profitabilitas terhadap kebijakan deviden pada kelompok saham Jakarta Islamic Index yang terdaftar di Bursa Efek Indonesia selama tahun 2013-2016, dapat dihitung dengan menggunakan analisis regresi linear berganda.

Dari hasil output SPSS, Maka model yang diperoleh untuk menunjukkan pengaruh likuiditas, solvabilitas dan profitabilitas adalah:

$$
\mathrm{Y}=-\mathbf{- 2 2 , 5 0 6}+\underset{1,251 \mathrm{X}_{3}}{\mathbf{0}, 177 \mathrm{X}_{1}}+\mathbf{2 0 , 0 3 5 \mathrm { X } _ { 2 } +}
$$

Berdasarkan model regresi diatas dapat dikemukakan hal-hal sebagai berikut:

\section{a. Nilai konstanta}

Nilai konstanta sebesar -22,506. Hal ini berarti bahwa jika koefisien regresi likuiditas dan profitabilitas adalah 0 ,

Corresponding Author: Andisartikaaa@gmail.com 16 maka koefisien regresi kebijakan deviden sebesar -22,506.

b. Likuiditas

Koefisien regresi $\left(\mathrm{X}_{1}\right)$ sebesar 0,177 menyatakan bahwa setiap penambahan satu satuan, maka likuiditas $\left(\mathrm{X}_{1}\right)$ akan meningkatkan kebijakan deviden sebesar 0,177 dengan asumsi variabel lain dianggap konstan.

c. Profitabilitas

Koefisien regresi $\left(\mathrm{X}_{3}\right)$ sebesar 1,251menyatakan bahwa setiap penambahan satu satuan, maka profitabilitas $\left(\mathrm{X}_{3}\right)$ akan meningkatkan kebijakan deviden sebesar 1,251dengan asumsi variabel lain dianggap konstan.

2. Uji autokorelasi

Uji autokorelasi muncul karena observasi yang berurutan sepanjang waktu berkaitan satu sama lainya.

Pengujian autokorelasi dengan melihat DW :

\begin{tabular}{|l|r|r|r|r|r|}
\hline Model & \multicolumn{1}{|c|}{$R$} & $R$ Square & $\begin{array}{c}\text { Adjusted } R \\
\text { Square }\end{array}$ & $\begin{array}{c}\text { Std. Error of the } \\
\text { Estimate }\end{array}$ & Durbin-Watson \\
\hline 1 & $.806^{\circ}$ & .645 & .620 & 14.31679 & 1.788 \\
\hline
\end{tabular}

Dari pengujian Durbin-Watson dalam penelitian ini, telihat dari tabel 11 dihasilkan nilai DW sebesar 1.788 yaitu berada diantara nilai $1.55-2.56$, yang berarti bahwa tidak terjadi gejala autokorelasi dalam model regresi ini.

3. Uji Koefisien Determinasi

Koefesien determinasi yang ditunjukan dari nilai adjusted $\mathrm{R}$ Square sebesar 0,620 berarti variabel independen yaitu Likuiditas (CR) dan profitabilitas (NPM) dapat menjelaskan variabel Kebijkakan Deviden (DPR) hanya sebesar 60,2\% saja, sedangkan sisanya sebesar $39,8 \%$ dijelaskan oleh variabel-variabel lain yang tidak (C) 2020 STIE TDN. All rights reserved 
termasuk dalam model penelitian. Artinya variabel bebas yang terdapat pada model ini cukup kuat untuk memprediksi variabel terikat.

\section{Uji t}

Uji $\mathrm{t}$ dilakukan untuk mengetahui apakah dalam model regresi variabel independen secara parsial berpengaruh signifikan terhadap variabel dependen.

Hasil uji signifikan persial masingmasing variabel sebagai berikut:

a. Variabel Current Ratio mempunyai pengaruh yang signifikan terhadap kebijakan deviden (DPR) karena mempunyai tingkat signifikansi lebih kecil dari 0,05 yaitu $0,00 \quad(0,00<$ 0,05). Berartidapat disimpulkan bahwa Likuiditas berpengaruh signifikan terhadap kebijakan deviden pada kelompok saham Jakarta Islamic Index yang terdaftar di Bursa Efek Indonesia.

b. Variabel Debt to Equity Ratio (DER) mempunyai pengaruh yang signifikan terhadap kebijakan deviden (DPR) karena mempunyai tingkat signifikansi lebih kecil dari 0,05 yaitu $0,00 \quad(0,00<0,05)$. Berartidapat disimpulkan bahwa Solvabilitas berpengaruh signifikan terhadap kebijakan deviden pada kelompok saham Jakarta Islamic Index yang terdaftar di Bursa Efek Indonesia.

c. Variabel Net Profit Margin (NPM) mempunyai pengaruh yang signifikan terhadap kebijakan deviden (DPR) karena mempunyai tingkat signifikansi lebih kecil dari 0,05 yaitu $0,004(0,004<0,05)$. Berartidapat disimpulkan bahwa Profitabilitas berpengaruh signifikan terhadap kebijakan deviden pada kelompok saham Jakarta Islamic Index yang

Corresponding Author: Andisartikaaa@gmail.com 17 terdaftar di Bursa Efek Indonesia.

Dari hasil data SPSS menunjukkan koefisien regresi yaitu sebagai berikut:

$\mathrm{Y}=\mathrm{a}+\mathrm{b}_{1} \mathrm{X}_{1}+\mathrm{b}_{1} \mathrm{X}_{2}+\mathrm{b}_{3} \mathrm{X}_{3}+\mathrm{e}$

$\mathrm{Y}=-22,506+0,177 \mathrm{X}_{1}+20,035 \mathrm{X}_{2}+$ $1,251 \mathrm{X}_{3}$

Berdasarkan persamaan regresi, maka dapat dijelaskan bahwa:

1. Likuiditas berpengaruh positif dan signifikan terhadap kebijakan deviden.

Berdasarkan hasil persamaan regresi berganda $\mathrm{Y}=-22,506+0,177 \mathrm{X}_{1}+$ $20,035 X_{2}+1,251 X_{3}$, menunjukkan bahwa hipotesis pertama yang menyatakan likuiditas memiliki pengaruh signifikan terhadap kebijakan deviden diterima dan dapat dibuktikan kebenarannya. Koefisien regresi Likuiditas (CR) senilai $(0,177)$, artinya kecenderungan perubahan likuiditas searah dengan kebijakan deviden.

Berdasarkan angka koefisien tersebut diartikan bahwa setiap kenaikan satu persen kebijakan deviden (DPR) dipengaruhi oleh kenaikan likuiditas (CR) sebesar 0,177. Hal ini berarti semakin besar likuiditas suatu perusahaan, maka kecenderungan perusahaan untuk membayar deviden juga semakin besar. Hal ini sesuai dengan teori yang dikemukakan oleh Home dan Wachowicz (2007:282) yang menyatakan bahwa Likuiditas perusahaan merupakan pertimbangan utama dalam banyak keputusan deviden. Karena deviden menunjukan arus kas keluar, semakin besar posisi kas dan keseluruhan likuiditas perusahaan, maka semakin besar kemampuan perusahaan untuk membayar deviden.

2. Profitabilitas berpengaruh positif dan signifikan terhadap kebijakan deviden.

Berdasarkan hasil persamaan regresi (C) 2020 STIE TDN. All rights reserved 
berganda $\mathrm{Y}=-22,506+0,177 \mathrm{X}_{1}+$ $20,035 X_{2}+1,251 X_{3}$, menunjukkan bahwa hipotesis ketiga yang menyatakan profitabilitas memiliki pengaruh signifikan terhadap kebijakan deviden diterima dan dapat dibuktikan kebenarannya. Koefisien regresi Solvabilitas (NPM) senilai $(1,251)$, artinya kecenderungan perubahan profitabilitas searah dengan kebijakan deviden. Berdasarkan angka koefisien tersebut diartikan bahwa setiap kenaikan satu persen kebijakan deviden (DPR) dipengaruhi oleh kenaikan Profitabilitas (NPM) sebesar 1,251. Hal ini berarti semakin besar profitabilitas (NPM) suatu perusahaan, maka kecenderungan perusahaan untuk melakukan pembayaran deviden bagi investor semakin besar. Hasil penelitian ini sejalan dengan hasil penelitian yang dilakukan oleh Sri Rejeki (2011) yang menemukan variabel Profitabilitas (NPM) berpengaruh positif dan signifikan terhadap kebijakan deviden (DPR).

\section{KESIMPULAN DAN SARAN}

Berdasarkan hasil penelitian dan pembahasan, maka disimpulkan sebagai berikut: (i) Pengaruh likuiditas terhadap kebijakan deviden pada kelompok saham Jakarta Islamic Index yang terdaftar di Bursa Efek Indonesia periode 20132016, menyatakan bahwa Likuiditas yang diukur dengan current ratio (CR) menunjukkan bahwa likuiditas berpengaruh positif dan signifikan terhadap kebijakan deviden. (ii) Pengaruh profitabilitas terhadap kebijakan deviden pada kelompok saham Jakarta Islamic Index yang terdaftar di Bursa Efek Indonesia periode 2013-

Corresponding Author: Andisartikaaa@gmail.com 18
2016, menyatakan bahwa profitabilitas yang diukur dengan net profit margin (NPM) menujukkan profitabilitas berpengaruh positif dan signifikan terhadap kebijakan deviden.

Berdasarkan kesimpulan di atas dikemukakan saran sebagai berikut: (i) Bagi investor yang mengharapkan tingkat keuntungan jangka panjang berupa deviden yang tinggi, maka sebaiknya investor memperhatikan efektifitas penggunaan utang yang dilakukan oleh perusahaan apakah telah dilakukan secara optimal oleh perusahaan atau tidak, karena pengguna yang sudah optimal dapat memberikan pengaruh yang positif terhadap kebijakan deviden (DPR) begitu pula sebaliknya penggunaan utang yang tidak optimal dapat mengurangi kemampuan perusahaan dalam melakukan pembayaran deviden kepada investor. (ii) Bagi pihak perusahaan untuk menjaga loyalitas pemegang saham terhadap perusahaan sebaiknya posisi kas dan kemampuan untuk memperoleh laba dapat dipertahankan dan ditingkatkan agar kemampuan perusahaan dalam membayar deviden tetap terjaga.

\section{DAFTAR PUSTAKA}

Ahmad Radoni dan Herni Ali. 2010. Manajemen Keuangan. Jakarta: Mitra Wacana Media.

Darmadji, Tjiptono dan Hendy $M$. Fakhruddin. 2011. Pasar Modal Di Indonesia. Edisi 3. Jakarta: Salemba Empat.

Ghozali, Imam. 2005. Aplikasi Analisis (c) 2020 STIE TDN. All rights reserved 
Multivariate dengan SPSS. Semarang: Badan Penerbit UNDIP.

Harahap, Sofian Safri. 2010. Analisis Kritis Atas Laporan Keuangan. Jakarta: Rajawali Persada.

Riyanto. 2001. Dasar-dasar Pembelanjaan Perusahaan. BPFE, Yogyakarta.

Sri Rejeki. 2011. Pengaruh Likuiditas, Profitabilitas, dan Ukuran Perusahaan Terhadap Kebijakan Deviden dan Harga Saham. Jurnal Ilmiah FE-UMM. Vol. 13 (2009) No. 1. ISSN Cetak 19786573, ISSN Online 2477-300x. Universitas

MuhammadiyahMetro Lampung.

Undang-Undang Pasar Modal. UndangUndang No. 8 Tahun 1995. LN No. 64 Tahun 1995, TLN No. 3608 .

Van Horne, James C. and John M. Wachowicz. 2007. Fundamentals of Financial Management, Prinsip-Prinsip Manajemen Keuangan. Jakarta : Salemba Empat. 